\title{
A Study on the Deterring Factors to Entrepreneurship among Graduates of Agriculture and Natural Resources: Case Study in Bushehr, Iran
}

\author{
Yousef Hedjazi, Masoud Rezaei \\ Department of Agricultural Extension and Education, University of Tehran, Karaj, Iran \\ Department of Agriculture, Iranian Institute of Encyclopedia Research, Tehran, Iran \\ yhejazi@ut.ac.ir
}

\begin{abstract}
The purpose of this research was to study deterring factors to entrepreneurship among graduates of agriculture and natural resources. A survey approach was used in this research. The statistical population included ninety eight graduates of agriculture and natural resources who are working in private or governmental business units in the province of Bushehr, Iran. A questionnaire was developed to interview the subjects of the study of which the validity and reliability were estimated based on the opinions of a panel of experts and Cronbach's alpha coefficient respectively. The results indicated that among personality factors, low self-confidence and low spirit of independence were the most important deterring factors to entrepreneurship. The results also revealed that a weak relation between university and business environment, insufficient practical and theoretical education, high risk of investment in the agriculture, and legal and administrative restrictions were the most important environmentally deterring factors. Based on this research finding, male graduates had a higher spirit of opportunity recognition and independence than female graduates.
\end{abstract}

Keywords: Agriculture, Deterring Factors, Entrepreneurship, Graduate

\section{Introduction}

The third millennium seems to be marked by a renewal of the entrepreneurial spirit which affects all countries and all sectors of economic and social life including business start-ups or takeovers, associations and even public services (Fayolle, 2007, p. 11). The encouragement of entrepreneurship as a possible source of job creation, empowerment and economic dynamism has captured the attention of both researchers and policy makers (Dzisi, 2014).Entrepreneurial activities are not only the incubator of technological innovation, but they also provide employment opportunities (Turker \& Selcuk, 2009). In developing countries, however, the university graduates' lack of interest and inability to engage in entrepreneurial activity seems to be the main issue (Shambare, 2013). Scholars have emphasized that entrepreneurship can improve youth livelihood and economic independence in developing countries (Awongbenle \& Iwuamadi, 2010; Chigunta, 2002).

The unemployment of the agricultural and natural resources graduates has become one of the main predicaments of the higher education system in Iran. Increased enrolment at higher education institutions has put more graduates into the labor market. In spite of that, there has not been an increase at the rate at which agricultural and natural resources graduates are employed. The consequences have been ignoring the potentials of these graduates, wasting educational assets, and political and economic pressures on the government and policymakers. Therefore, the need to address this issue more seriously has become apparent evermore. One of the main prerequisites for facilitating agricultural graduates' employment is encouraging them to do business (create new businesses, self-employment, intra preneurship and so on). It is therefore sensible to assume that entrepreneurship is a solution to the agricultural and natural resources graduates' unemployment problem (Setiawan, 2014; Shambare, 2013).Graduates who are more mature are more likely to be intended towards entrepreneurship (Sandhu, Sidique \& Riaz, 2011). For this reason, further attention should be paid to developing entrepreneurship spirit and abilities of university graduates. In other words, graduates must be able to recognize present and future opportunities, so that through their achieved knowledge and expertise they may perform the needed actions for better exploitation of those opportunities, and through establishment of a business, get some earnings. In this regard, educational systems must try to move obstacles away from entrepreneurship, innovation and creativity. 
Entrepreneurship is a multidimensional phenomenon that cuts across disciplines. The phenomenon can be studied from many different viewpoints such as economy, sociology, financial theory, history, psychology or anthropology (Bjerke, 2007, p. 73). Historically scholars progressed in their efforts by asking questions about who is an entrepreneur (trait approach), what environment forms an entrepreneur (demographicsociological approach), and why somebody chooses to become an entrepreneur (behavioral approach). Where initially scholars focused on the traits of an entrepreneur, currently the behavior itself is the main dimension of interest (Weber, 2012, p. 36). Entrepreneurship is extensively being accepted as an important means and a useful alternative for income generation in young people (Awongbenle \& Iwuamadi, 2010; Fatoki \& Chindoga, 2011; Ryan, 2003).

In order to investigate entrepreneurship among graduates of agriculture and natural resources, a definition of entrepreneurship is necessary. In defining entrepreneurship, there is significant debate among researchers and various definitions have provided to explain entrepreneurship. There are, in principle, three different methods to define entrepreneurs and entrepreneurship: 1) using those skills characterizing entrepreneurs; 2) using those processes and events which are part of entrepreneurship; and 3) using those results that entrepreneurship leads to (Davidsson, 2003). Most definitions are a mix of these three. According to Sathiabama (2010), entrepreneurship is a dynamic process of creating wealth by individuals or groups of individuals. Coulter (2001, p. 6) defined entrepreneurship as "the process whereby an individual or a group of individuals use organized efforts and means to pursue opportunities to create value and grow by fulfilling wants and needs through innovation and uniqueness, no matter what resources are currently controlled". Bjerke (2007, p. 17) believed that in order to "better understand our new entrepreneurial society, entrepreneurship should only be specified by its results. In other words, Entrepreneurship = to create new user value". Kuratko and Hodgetts (2004, p. 30) stated that "entrepreneurship is a dynamic process of vision, change, and creation. It requires an application of energy and passion towards the creation and implementation of new ideas and creative solutions". Essential ingredients include the willingness to take calculated risks - in terms of time, equity, or career; the ability to formulate an effective venture team; the creative skill to marshal needed resources; the fundamental skill of building a solid business plan; and, finally, the vision to recognize opportunity where others see chaos, contradiction, and confusion. This paper adopts a definition of entrepreneurship along the lines proposed by Coulter (2001). Graduate entrepreneurship is a process taken by a graduate to start a business in terms of an individual career orientation (Rwigema \& Venter, 2004).

An entrepreneur is someone who perceives and even creates an opportunity and establishes an organization to pursue it. The entrepreneurial process includes all the activities and actions that are part of perceiving and creating opportunities and establishing organizations to pursue them. This process includes personal, sociological, organizational, and environmental factors that give birth to a new enterprise and influence how it develops from an idea to a viable enterprise (Bygrave and Zacharakis, 2011, p.p. 49-50). Entrepreneurs not only create new businesses but also increase employment opportunities that lead to the creation of sources of new discoveries, new technologies, and innovations (Iskandarini, 2014). The entrepreneurial process is, per $s e$, an evolutionary mechanism in which a person's abilities to take the opportunity of becoming a new agent (entrepreneur) turns into the capacity of identifying and evaluating an opportunity, in pursuing resources and planning how to use this opportunity. Thus the entrepreneurial process is creative because the entrepreneur re-elaborates resources and opportunities, involving human abilities and intangible factors (Gurrieri, Lorizio \& Stramaglia, 2014, p. 3).

Researches in the field of entrepreneurship broadly analyze the motivation that drives the entrepreneur to start a new business (Iskandarini, 2014). However, there is still a general lack of in-depth research on youth entrepreneurship, especially as it relates to the key constraints that impede young people from starting and maintaining a successful business in a developing country context (Dzisi, 2014). This research seeks to address this gap, because identifying the actual barriers to the creation of new businesses in agricultural and natural resources domain can help planners and policymakers to remove or decrease entry barriers and improve business formation in agricultural sector.

Past researches showed the following to be the most important obstacles to starting a business: lack of entrepreneurial and managerial skills, training obstacles, and lack of technical knowledge (Kvedaraite, 2014; 
Dzisi, 2014; Jafarnejad, Abbaszadeh, Ebrahimi, and Abtahi, 2013; Sherazi, Iqbal, Asif, Rehmanand, \& Hussain Shah, 2013; Fatoki, 2010; Herrington, Kew, and Kew, 2009; Papulova and Makros, 2007; Herrington and Wood, 2007; Moy,Luk, Sheehan, and Sammapan, 2001); lack of information on creating business (Kvedaraite, 2014; Jafarnejad et al., 2013); financial constrains and poor possibilities to receive a loan and high costs of receiving a loan (Kvedaraite, 2014; Dzisi, 2014; Jafarnejad et al., 2013; Mehrez, 2014; Sherazi et al., 2013; Ooi and Ahmad, 2012; Fatoki and Chindoga, 2011; Awongbenle and Iwuamadi, 2010; Fatoki, 2010; Lougui, 2010; Atieno, 2009; Chu, Benzing, and McGee, 2007; Kozan, Oksoyand, and Ozsoy, 2006; Sarri and Trihopoulou, 2005; Bitzenis \& Nito, 2005; Pretorius and Shaw, 2004; Ozsoy, Oksoyand, \& Kozan, 2001); high labor cost and high operating cost (Kvedaraite, 2014; Ooi and Ahmad, 2012; Moy et al., 2001); public bureaucracy, strict government regulation and lack of government support (Mehrez, 2014; Owusu-Ansah and Poku, 2012; Fatoki, 2010; Zhuplev \& Shtykho, 2009; Jamali, 2009; Bitzenis \& Nito, 2005;Lamei, 2002;Macculloch, 2001; Moy et al., 2001); crime and corruption (Sherazi et al., 2013; Fatoki, 2010; Arzeni, 2004); social and technological obstacles (Kvedaraite, 2014; Mehrez, 2014; Sherazi et al., 2013; Sarani, Shahpasand, \& Savari, 2013); management and infrastructure obstacles (Sherazi et al., 2013); taxation, competitive environment and aversion to risk (Ooi and Ahmad, 2012; Sandhu, Sidique, \& Riaz, 2011; Fatoki, 2010; Benzing et al., 2009; Kazela, 2009; Bitzenis \& Nito, 2005); lack of social networking and negative social and cultural attitude to entrepreneurship (Dzisi, 2014; Sandhu et al., 2011); lack of resources (Sandhu et al., 2011; Pretorius and Shaw, 2004), and difficulty in recruiting good and reliable staff (Jafarnejad et al., 2013; Benzing et al., 2009; Zhuplev \& Shtykho, 2009).

Drawing from the extant literature mentioned above, it was observed that youth and university graduates experience a multitude of barriers limiting their participation in entrepreneurial activities. For that reason, this study investigates deterring factors to entrepreneurship among graduate of agricultural and natural resources. Consequently, the present research is looking for the answers to the following questions:

1- How is the level of entrepreneurial spirit of the graduates of agriculture and natural resources (personality characteristics)?

2- What are the most important environmental and personality deterring factors to entrepreneurship among graduates of agriculture and natural resources?

3- What meaningful difference is there, between gender, background of cooperation with business units, university (the place of education), and education level, with personality characteristics of the entrepreneur?

\section{Methodology}

A descriptive method was applied in the research work. The statistical population was all agriculture and natural resources graduates of the southern province of Bushehr, who graduated with B.Sc. or M.Sc. degrees from agriculture faculties (governmental or non-governmental universities) during 1991-2001. During the abovementioned period of time, these graduates who are 98 in number $(\mathrm{N}=98)$ were able to establish a business in the fields of agricultural productive or support services, individually or in cooperation with others. These business units were recognized through the organizations related to Jihad-e-Keshavarzi (Ministry of Agriculture of Iran) which have some kind of relations with the target units. The questionnaire used for data collection consisted of 3 sections: the first section contained demographic characteristics of the graduates (such as: gender, graduation year, education level, and conditions of the university where they studied and so on), in the second section there were 20 questions about those personality characters which are influential in entrepreneurial spirit of the subjects (like risk taking, opportunity recognition, need for independence, internal locus of control, moralities, self-confidence, and looking for success), and the third section contains 24 questions about environmental barriers influencing entrepreneurship of agriculture and natural resources graduates of Bushehr province (that divided into three groups namely: constrains of agricultural sector, constrains of the higher education system, and administrative and managerial constrains). The content validity of the questionnaire was assessed by the experts of the agricultural education inspecting the relevance of the items and the unambiguity of their formulation. Cronbach's alpha was estimated for the scales used in the study to ensure internal consistency among the items. The reliability of the scales was 0.75 , $0.91,0.91$ and 0.91 for personality characteristics, constrains of agricultural sector, constrains of the higher education system, and administrative and managerial constrains, respectively, which is considered to be an acceptable index for field research. Descriptive statistical analysis and comparison tests were used for data analysis. All data were analyzed using the SPSS for Windows (version 16). 


\section{Results and Discussion}

Among 98 graduates, $66.2 \%$ were male and $33.8 \%$ were female. $63.1 \%$ of the graduates had graduated from governmental universities and $36.9 \%$ of them from Azad University. $86.1 \%$ of the subjects had B.Sc. degrees, while $13.9 \%$ of them had M.Sc. degrees. $22.2 \%$ of the graduates had graduated from faculties between 1991 $1994,20 \%$ between 1995-1998, and 55.4\% of them between1999-2002.

Personality Deterring Factors to Entrepreneurship: Table 1 shows the responses to items contained in personality deterring factors scale. Among personality factors, low self-confidence $(M=1.86, S D=0.33)$ and low spirit of independence $(M=1.97, S D=0.87)$ were specified as the major constrains to entrepreneurial spirit, respectively. As it is seen in Table 1 , paying attention to moralities $(M=2.62, S D=0.35)$ and opportunity recognition $(M=2.29, S D=0.46)$ have high values. It means that the status of paying attention to moralities and opportunity recognition among graduates of agriculture and natural resources was high.

Table 1: Personality deterring factors to entrepreneurship

\begin{tabular}{lll}
\hline Variables & Mean & Standard Deviation \\
\hline Spirit of independence & 1.97 & 0.87 \\
Internal locus of control & 2.26 & 0.55 \\
Risk taking & 2.26 & 0.47 \\
Opportunity recognition & 2.29 & 0.46 \\
Self-confidence & 1.86 & 0.33 \\
Looking for success & 2.04 & 0.30 \\
Considering moralities & 2.62 & 0.35 \\
\hline
\end{tabular}

Environmental Deterring Factors to Entrepreneurship: Researchers have categorized constrains and barriers facing entrepreneurs in various ways. Kvedaraite (2014) divided reasons and obstacles for youth's unwillingness to do business and/or get involved in entrepreneurship into two groups: The first one were intrinsic factors, involving cultural-psychological, demographic and social-economic factors, as well as person's characteristics, values, skills, perception and behavior; the second one were extrinsic factors caused by market (finance, labor market, information) imperfections. Moy et al. (2001) stated that exogenous and endogenous factors were the main challenges/obstacles faced when starting and sustaining new enterprises among students. In this research, environmental deterring factors to entrepreneurship were divided into three groups: constrains of agriculture sector, constrains of higher education system, and administrative and managerial constrains, described in the following paragraphs.

The results revealed that risk of investment in agriculture sector $(M=2.29, S D=0.77)$ and Society's view of agricultural work $(M=1.97, S D=0.85)$ were two of the most important obstacles to graduate entrepreneurship in Busher (Table 2). Similar findings were reported by other researchers (Dzisi, 2014; Fatoki, 2010; Mehrez, 2014; Moy et al., 2001; Sandhu et al., 2011; Sarani et al., 2013). Today, the function of agricultural sector has extremely changed around the world. At one time the function of agricultural sector was almost exclusively to satisfy the demand for foods; nowadays its function is much broader. The agricultural sector today provides considerable non-monetary assets, such as job opportunities, employment, economic survival of rural areas and rural development (Gurrieri, Lorizio \& Stramaglia, 2014, p. 18). For this reason, policymakers should remove barriers and improve business environment in agriculture sector.

Table 2: Constrains of agriculture sector

\begin{tabular}{lll}
\hline Variables & Mean & Standard Deviation \\
\hline Risk of investment in agriculture sector & 2.29 & 0.77 \\
Pricing system for agricultural products & 1.28 & 0.82 \\
Society's view of agricultural work & 1.97 & 0.85 \\
Late yield of agricultural activities & 1.94 & 0.86 \\
\hline
\end{tabular}


Government activities, both directly and indirectly, influence business activity and government can be seen as the biggest business enterprise at national or local level (Worthington and Britton, 2006; 7). The finding indicated that legal and administrative restrictions $(M=2.20, S D=0.75)$ were crucial deterring factors to entrepreneurship in regard to administrative and managerial constrains (Table 3). This finding is consistent with previous researches (Sherazi et al., 2013; Fatoki, 2010; Klapper, Laeven \& Rajan, 2006; Bitzanis and Nito, 2005; Moy et al., 2001).

Table 3: Administrative and managerial constrains

\begin{tabular}{lll}
\hline Variables & Mean & Standard Deviation \\
\hline Legal and administrative restrictions & 2.20 & 0.75 \\
Information supply about the present entrepreneurial opportunities & 2.19 & 0.79 \\
Government's financial and credit supports & 2.31 & 0.85 \\
\hline
\end{tabular}

Based on the results, a weak relation between university and business environment $(M=2.56, S D=0.81)$ and insufficient practical education $(M=2.54, S D=0.71)$ were two main deterring factors to entrepreneurship regarding higher education system (Table 4). The finding is in line with the result obtained by Kvedaraite, (2014), Jafarnejad et al., (2013), Sherazi et al. (2013), Fatoki, (2010) and Moy et al. (2001). Poor education can lessen the employability of individuals, or weaken their entrepreneurial skills (Global business school network, 2013). Herrington et al. (2009) reported that the quality of entrepreneurship training apart from academic qualification is poor and therefore local entrepreneurs and graduate entrepreneurs have poor business and managerial skills.

Table 4: Constrains of higher education system

\begin{tabular}{lll}
\hline Variables & Mean & Standard Deviation \\
\hline Insufficient practical education & 2.54 & 0.71 \\
Insufficient theoretical education & 2.46 & 0.75 \\
A weak relation between university and business environment & 2.56 & 0.81 \\
Experimental methods and learning while working & 2.18 & 0.86 \\
Suitability of educational programs with entrepreneurial business & 2.14 & 0.87 \\
characteristics & & \\
\hline
\end{tabular}

Table 5: Comparison of the subjects regarding individual attributes about personality characteristics for entrepreneurship

\begin{tabular}{|c|c|c|c|c|c|c|c|c|c|c|}
\hline \multirow[t]{2}{*}{ Variables } & \multicolumn{2}{|c|}{$\begin{array}{l}\text { Background for } \\
\text { cooperation } \\
\text { with business }\end{array}$} & \multicolumn{2}{|c|}{ Gender } & \multicolumn{2}{|c|}{$\begin{array}{l}\text { Graduation } \\
\text { year }\end{array}$} & \multicolumn{2}{|c|}{$\begin{array}{l}\text { University of } \\
\text { graduation }\end{array}$} & \multicolumn{2}{|c|}{$\begin{array}{l}\text { Education } \\
\text { level }\end{array}$} \\
\hline & $t$ & Sig & $t$ & Sig & $f$ & Sig & $t$ & Sig & $f$ & sig \\
\hline Risk taking & -0.85 & 0.39 & 0.71 & 0.47 & 0.510 & 0.60 & -1.71 & 0.09 & 0.447 & 0.64 \\
\hline $\begin{array}{l}\text { Opportunity } \\
\text { recognition }\end{array}$ & 0.44 & 0.66 & 2.35 & $0.02^{*}$ & 2.283 & 0.11 & 1.48 & 0.14 & 1.045 & 0.35 \\
\hline Independence & -0.72 & 0.46 & 1.49 & $0.05^{*}$ & 2.319 & 0.10 & -1.42 & 0.16 & 0.007 & 0.99 \\
\hline $\begin{array}{l}\text { Internal locus of } \\
\text { control }\end{array}$ & 1.29 & 0.20 & 0.96 & 0.33 & 0.001 & 0.99 & -0.62 & 0.53 & 0.440 & 0.64 \\
\hline Moralities & 1.31 & 0.19 & -1.55 & 0.12 & 0.0009 & 0.37 & -0.13 & 0.89 & 0.970 & 0.38 \\
\hline Self confidence & 0.38 & 0.70 & -1.75 & 0.08 & 0.218 & 0.80 & 0.49 & 0.62 & 1.081 & 0.34 \\
\hline $\begin{array}{l}\text { Looking for } \\
\text { success }\end{array}$ & -1.08 & 0.28 & 0.31 & 0.75 & 0.370 & 0.69 & 1.50 & 0.13 & 1.616 & 0.20 \\
\hline $\begin{array}{l}\text { Entrepreneurial } \\
\text { spirit }\end{array}$ & -0.23 & 0.81 & 0.96 & 0.33 & 0.393 & 0.67 & -0.10 & 0.91 & 0.484 & 0.61 \\
\hline
\end{tabular}


Among the collection of environmental deterring factors to entrepreneurship, a weak relation between university and business environment, insufficient practical and theoretical education, risk of investment in agriculture, and legal and managerial restrictions had the greatest deterring power respectively; while pricing system for agricultural products and late yield of agricultural activities had the modest deterring power to entrepreneurship respectively. Personality characteristics of the subjects regarding gender, background of cooperation with business units, year of graduation, and education level, were compared through $F$ and $t$ test. As it is seen in Table 5, there was a significant difference between opportunity recognition of males $(M=2.39, S D=0.40)$ and females $(M=2.11, S D=0.52 ; t=2.35, p=0.02)$, in which males had higher opportunity recognition spirit than females. In relation to spirit of independence, there was a significant difference between the male graduates $(M=2.12, S D=0.83)$ and female graduates $(M=1.68$, $S D=0.82 ; t=1.49, p=0.05$ ), and males' spirit of independence was higher than females. Much research has shown that males are more likely to venture into business compared to females (Dunn, 2004; Sandhu, et al. 2011; Veciana, Aponte, \& Urbano, 2005; Chigunta, 2002; Fatoki and Chigonda, 2011).

\section{Conclusion}

Students graduating from higher education institutions (HEIs) enter an environment that is changing and unstable. Technology and contingent factors are changing the world of work opportunity on a daily basis (Collins, Hannon \& Smith, 2004). Providing jobs for a growing population of graduates is one of the most pressing challenges facing the developing world such as Iran. Initiatives that focus on increasing entrepreneurship and increasing employment share a great deal in common, as entrepreneurship can be seen as a special form of employability (Global business school network, 2013). The overall aim of this research was to study the deterring factors to entrepreneurship among graduates of agriculture and natural resources. This study found that low self-confidence, risk of investment in agriculture sector, legal and administrative restrictions, and a weak relation between university and business environment were four important barriers to graduates' entrepreneurship. The results of the research also showed that there was a significant difference between male and female graduates in relation to opportunity recognition and spirit of independence, and male graduates were better than female graduates. Considering these points, paying attention to faculties of agriculture, quantity and quality of the presented education, and their adaptation with characteristics and purposes of entrepreneurial activities are very important. Therefore, providing graduates with more entrepreneurial training and exposing them to entrepreneurial role models can give them the tools to create their own employment. Furthermore, planners and policy makers should change regulations that are unnecessarily restrictive, and should also provide additional sources of funding for entrepreneurs. They should also improve the business environment in agricultural sector, promote a climate of entrepreneurship, and encourage graduates to create their own business and self-employment. The results of this research can help universities that train agricultural and natural resources students, and organizations that employ those students, to better understand the obstacles to entrepreneurship, and will enable them to promote entrepreneurial actions of graduates by overcoming these barriers.

\section{References}

Arzeni, S. (2004). Entrepreneurship: a catalyst for urban regeneration: Retrieved April 16 2015, from: http://www.iaabd.org/2009_iaabd_proceedings/track7m.pdf

Atieno, R. (2009). Linkages, access to finance and the performance of small-scale enterprises in Kenya. Journal of accounting and business research, 3(1), 33-48.

Awongbenle, A. C. \& Iwuamadi, K. C. (2010). Youth unemployment: entrepreneurship development program as an intervention mechanism. African journal of business management, 14(6), 831-835.

Benzing, C., Chu, H. M. \& Kara, O. (2009). Entrepreneurs in Turkey: a factor analysis of motivations, success factors and problems. Journal of small business management, 47(1), 58-91.

Bitzenis, A. \& Nito, E. (2005). Obstacles to entrepreneurship in a transition business environment: the case of Albania. Journal of small business and enterprise development, 12(4), 564-578.

Bjerke, B. (2007). Understanding entrepreneurship. USA: Edward Elgar Publishing, Inc.

Bygrave, W. \& Zacharakis, A. (2011). Entrepreneurship. Second edition, USA: John Wiley \& Sons.

Chigunta, F. (2002). Youth entrepreneurship: meeting the key policy challenges: Retrieved April 14 2015, from: http://www.bg.entrep.ta 
Chu, H. M., Benzing, C. \& McGee, C. (2007). Ghanaian and Kenyan entrepreneurs: A comparative analysis of their motivations, success characteristics, and problems. Journal of developmental entrepreneurship, 12(3), 295-322.

Collins, L., Hannon, P. D. \& Smith, A. (2004).Enacting entrepreneurial intent: the gaps between students' needs and higher education capability. Education \& training, 46(8/9), 454-468.

Coulter, M. (2001). Entrepreneurship in Action, Upper Saddle River, NJ: Prentice Hall.

Davidsson, P. (2003). The domain of entrepreneurship research: some suggestions. In cognitive approaches to entrepreneurship, J Katz and D Shepherd (eds.),pp. 315-372, Cambridge, MA: Elsevier Science.

Dunn, C. (2004). Background of nascent entrepreneurs: Retrieved April 15 2015, from: www.sbaer.uca.edu/research/icsb/2004/Papers\%20pdf/010.pdf.

Dzisi, S. (2014). Youth entrepreneurship: investigating obstacles to youth enterprise creation and development. International journal of economics, commerce and management, 2(7), 1-21.

Fatoki, 0.0. (2010). Graduate entrepreneurial intention in South Africa: motivations and obstacles. International journal of business and management, 5(9), 87-98.

Fatoki, O. O. \& Chindoga, L. (2011).An investigation into the obstacles to youth entrepreneurship in South Africa. International business research, 4(2), 161-169.

Fayolle, A. (2007). Entrepreneurship and new value creation: the dynamic of the entrepreneurial process. New York: Cambridge University Press.

Global business school network. (2013). Education, employment and entrepreneurship: a snapshot of the global jobs challenges: Retrieved Jun 13 2015, from: http://c.ymcdn.com/sites/www.gbsnonline.org/resource/collection

Gurrieri, A. R., Lorizio, M. \& Stramaglia, A. (2014). Entrepreneurship networks in Italy: The role of agriculture and services. London: Springer.

Herrington, M. \& Wood, T. (2007). Global Entrepreneurship Monitor: South African Report: Retrieved April 16 2015, from: http://www.gemconsortium.org/files.aspx?Ca_ID=126.

Herrington, M., Kew, J. \& Kew, P. (2009). Global Entrepreneurship Monitor, South African report: Retrieved April 16 2015, from: http://www.gbs.nct.ac.za/gbswebb/userfiles/gemsouthafrica2000pdf

Iskandarini, A. (2014). The impact of entrepreneurial barrier toward entrepreneurial intention for decreasing unemployment through community empowerment. Procedia - social and behavioral sciences, 115, 166-174.

Jafarnejad, A., Abbaszadeh, M. A., Ebrahimi, M. \& Abtahi, S. M. (2013).Analysis of barriers to entrepreneurship in Small and Medium-sized Enterprises (SMEs). International journal of academic research in economics and management sciences, 2(4), 207-216.

Jamali, D. (2009). Constraints and opportunities facing women entrepreneurs in developing countries: A relational perspective. Gender in management: an international journal, 24(4), 232-251.

Kazela, N. (2009). The roadmap of youth entrepreneurship: Retrieved April 10 2015, from: http://www.wcf2009.org/program

Klapper, L., Laeven, L. \& Rajan, R. (2006). Entry regulation as a barrier to entrepreneurship. Journal of financial economics, 82, 591-629.

Kozan, M. K., Oksoyand, D. \& Ozsoy, O. (2006). Growth plans of small business in Turkey: individual and environmental influences. Journal of small business management, 4(11), 114-129.

Kuratko, D. F. \& Hodgettsm, R. M. (2004). Entrepreneurship: Theory, Process, Practice, 6th edition, Stanford, CT: Thomson South-Western.

Kvedaraite, N. (2014). Reasons and obstacles to starting a business: experience of students of Lithuanian higher education institutions. Management, 19(1), 1-16.

Lamei, B. (2002). Developing and training entrepreneurship in Iran: barriers and solutions. Ministry of Labor \& Social Affairs, Institute of Labor \& Social Security, 1(45), 26-32.

Lougui, M. (2010). Identifying obstacles encountered by Swedish entrepreneurs? Evidences from the startline, Master's thesis in economics of innovation and growth, School of architecture and the built environments, Royal institute of technology, Sweden.

Macculloch, F. (2001). Government administrative burdens on SMEs in East Africa: reviewing issues and actions. Economic affairs, 21(2), 10-16.

Mehrez, A. (2014). A study of barriers to entrepreneurship in emerging economies: the case of Qatar. In proceedings of 29 th international business research conference, Australia, Sydney. 
Moy, J., Luk, V., Sheehan, B. \& Sammapan, N. (2001). A comparative study on the perceptions of university business students in Hong Kong and Thailand: Why do they become entrepreneurs: Retrieved April 10 2015, from: http://net2.hkbu.edu.hk/ ied/publications/wp/WP200102.pdf

Ooi, Y. K. \& Ahmad, S. (2012). A study among university students in business start-ups in Malaysia: Motivations and obstacles to become entrepreneurs. International journal of business and social science, 3(19), 181-192.

Owusu-Ansah, W. \& Poku, K. (2012).Entrepreneurship education, a panacea to graduate unemployment in Ghana? International journal of humanities and social science, 2(15), 211-220.

Ozsoy, O., Oksoyand, D. \& Kozan, K. (2001).The characteristics of Turkish entrepreneurs and their enterprises. Long Island, New York: College of Business, Alfred University.

Papulova, Z. \&Makros, M. (2007).Importance of managerial skills and knowledge in management for small entrepreneurs. E-leader, 1, 1-8.

Pretorius, M. \& Shaw, G. (2004).Business plan in bank-decision making when financing new ventures in South Africa. South African journal of economics and management science, 7(2), 221-242.

Rwigema, H. \&Venter, R. (2004). Advanced entrepreneurship (3rd Ed.) Cape Town: Oxford University Press.

Ryan, C. (2003). Program priorities 2003-2006 youth enterprise development, Strategic Paper by the Common Wealth Secretariat, London. Common Wealth Secretariat.

Sandhu, M. S., Sidique, S. F. \& Riaz, S. (2011). Entrepreneurship barriers and entrepreneurial inclination among Malaysian postgraduate students. International journal of entrepreneurial behavior \& research, $17(4), 428-449$.

Sarani, V., Shahpasand, M. R. \& Savari, M. (2013). Analysis of barriers to entrepreneurship among the rural women in Divan-Darreh city using by grounded theory. International research journal of applied and basic sciences, 4(5), 1302-1308.

Sarri, K. \& Trihopoulou, A. (2005). Female entrepreneurs' personal characteristics and motivation: a review of the Greek situation. Women in management review, 20(1), 24-36.

Sathiabama, K. (2010). Rural women empowerment and entrepreneurship development: Retrieved April 10 2015, from: http://www.microfinancegateway.org/ga

Setiawan, J. L. (2014). Examining entrepreneurial self-efficacy among students. Procedia - social and behavioral sciences, $115,235-242$.

Shambare, R. (2013). Barriers to student entrepreneurship in South Africa. Journal of economics and behavioral studies, 5(7), 449-459.

Sherazi, S. K., Iqbal, M. Z., Asif, M., Rehmanand, K. \& Hussain Shah, S. S. (2013). Obstacles to small and medium enterprises in Pakistan: Principal component analysis approach. Middle-East journal of scientific research, 13(10), 1325-1334.

Turker, D. \& Selcuk, S. S. (2009). Which factors affect entrepreneurial intention of university students? Journal of European industrial training, 33(2), 142-159.

Veciana, J. M., Aponte, M. \& Urbano, D. (2005). University students' attitudes towards entrepreneurship: A two countries comparison. International entrepreneurship and management journal, 1, 165-182.

Weber, R. (2012). Evaluating entrepreneurship education. Germany: Springer Gabler.

Worthington, I. \& Britton, C. (2006).The business environment. Fifth edition, Prentice Hall.

Zhuplev, A. \& Shtykhno, D. (2009). Motivations and obstacles for small business entrepreneurship in Russia: fifteen years in transition. Journal of East-West business, 15(1), 25-49. 